NBER WORKING PAPER SERIES

\title{
WORKING THE SYSTEM: FIRM LEARNING AND THE ANTIDUMPING PROCESS
}

\author{
Bruce A. Blonigen \\ Working Paper 10783 \\ http://www.nber.org/papers/w10783 \\ NATIONAL BUREAU OF ECONOMIC RESEARCH \\ 1050 Massachusetts Avenue \\ Cambridge, MA 02138 \\ September 2004
}

This paper was prepared for the conference, "The 100th Anniversary of Anti-Dumping Regulation", sponsored by the Leverhulme Centre for Research on Globalisation and Economic Policy (GEP) at the University of Nottingham, United Kingdom, and held June 2004. I thank my discussant, Doug Nelson, as well as other conference participants for many insightful and useful comments. Any remaining errors or omissions are the responsibility of the author. The views expressed herein are those of the author(s) and not necessarily those of the National Bureau of Economic Research.

(C2004 by Bruce A. Blonigen. All rights reserved. Short sections of text, not to exceed two paragraphs, may be quoted without explicit permission provided that full credit, including $\odot$ notice, is given to the source. 
Working the System: Firm Learning and the Antidumping Process

Bruce A. Blonigen

NBER Working Paper No. 10783

September 2004

JEL No. F13

\section{$\underline{\text { ABSTRACT }}$}

This paper takes the first systematic look at how prior experience by US firms in filing US AD petitions affects future AD filing activity and outcomes. Such prior experience may affect both the cost of filing petitions, as well as the likelihood of successful outcomes and dumping margin magnitudes. Statistical analysis of data on US AD cases finds that prior AD experience leads to greater filing activity and likelihood of affirmative decisions or suspension agreements, but significantly lower dumping margins. The latter result suggests that experience does not affect dumping margins as much as it lowers filing costs, leading to petitioning of weaker cases.

Bruce A. Blonigen

Department of Economics

University of Oregon

Eugene, OR 97403-1285

and NBER

bruceb@uoregon.edu 


\section{Introduction}

Antidumping (AD) investigations begin with a petition by an "interested" domestic party. This is typically a producer (or group of producers) competing with the imported product subject to the investigation. $\mathrm{AD}$ authorities then determine whether there is indeed dumping, defined as pricing by the foreign firm below "fair" or "normal" value, and whether such trade practices are injuring the domestic industry represented by the petitioners. If these criteria are satisfied, an $\mathrm{AD}$ duty equal to the calculated dumping margin is applied to the imported products. In the United States (US), the dumping margin calculations are conducted by the International Trade Administration of the US Department of Commerce (USDOC), while the US International Trade Commission (USITC) makes the injury determination.

There is a substantial amount of interaction between petitioners and AD authorities in the US. The petitioning party must present the $\mathrm{AD}$ authorities with a reasonable petition that presents their case for the investigation and then provide substantial information, as well as legal analysis and arguments, during the course of the investigation. The legal details, as well as the practical issues of how government agencies apply the law, are substantial. This complexity of petitioning and obtaining $\mathrm{AD}$ remedies suggests that prior experience, or learning, by petitioning parties may play an important role in antidumping filings and outcomes. In particular, prior experience is hypothesized to lower future filing costs, while also increasing petitioners' effectiveness in arguing their case and generating higher probabilities of favorable outcomes. Such learning effects should clearly increase filing activity, but its effect on outcomes is theoretically ambiguous as we detail more in the next section. While learning may increase nonnegative decision probabilities in these cases, the greater selection of weaker cases due to lower filing costs may outweigh such effects. 
This paper is the first to systematically estimate and examine the potential effects of learning on AD filings and outcomes. We use detailed data on US AD filings and outcomes that span the 1980s and 1990s to examine our hypotheses. Our empirical analysis reveals that learning has a large impact on filing activity. Everything else equal, including controls for timeinvariant industry effects, prior AD activity in a 4-digit SIC industry increases the likelihood of an $\mathrm{AD}$ filing in a year for an average industry from a base of $2 \%$ to $9 \%$. Learning (or prior experience) by petitioners also affects US AD outcomes. In the case of $\mathrm{AD}$ margins, prior experience actually leads to dumping margins that are about 12 percentage points lower, where the sample average dumping margin is $43.5 \%$. This evidence is consistent with a scenario where the effect of prior experience on filings costs (and the resulting increase in the filing of weaker cases) dominates any effect that experience has on petitioners obtaining higher dumping margins. On the other hand, we find evidence that the probability of an affirmative decision increases from about $42 \%$ to $54 \%$ when petitioners have prior experience, despite this same selection effect of weaker cases from lower filing costs. In similar manner, prior experience raises the probability of a suspension agreement from $3 \%$ to $7 \%$. In summary, prior experience leads to increased filing activity and evidence suggests that this increased filing volume is due to weaker cases. Prior experience increases petitioners' abilities to achieve higher probabilities of favorable outcomes, but little impact on dumping margins, such that the increase in weaker cases leads to significantly lower dumping margins for repeat petitioners. On a final note, while the steel industry is responsible for the bulk of repeat petitioners in US AD cases, our results are not steel-specific and do not change substantially when we omit observations on steel industry AD activity from our sample.

The rest of the paper proceeds as follows. The next section provides a simple theoretical discussion for how prior experience may affect filing activity and US AD outcomes. Section 3 
provides descriptive statistics of the patterns of repeat petitioners in the US AD data before section 4 provides the paper's primary statistical analysis of the effects of prior experience.

\section{How Prior Experience May Matter for Petitioning Behavior and AD Case Outcomes}

Conditional on having a petition filed, an obvious hypothesis is that prior experience leads to a higher probability of an affirmative $\mathrm{AD}$ decision, everything else equal. The necessary assumptions for this effect are 1) there is sufficient ambiguity in the application of the law, 2) petitioners have input into resolving this ambiguity for their particular case, and that 3) petitioners prior experience allows them to learn how to better argue their case. All of these assumptions seem likely valid in US AD cases. There is clearly ambiguity in the application of the law as seen by the literature detailing the discretionary practices used by the Department of Commerce to calculate dumping margins to the literature finding that non-economic factors affect USITC determinations. ${ }^{1}$ Petitioners also have a clear role in resolving this ambiguity as seen in public responses given by both agencies (the USITC and the USDOC) to issues raised by the petitioner in their rulings. Additionally, rulings can be appealed or brought before dispute settlement proceedings. Given this, it is not difficult to imagine that petitioners improve in their ability to achieve more favorable outcomes through their prior AD case experiences.

However, this discussion does not consider the effect of experience on whether an $\mathrm{AD}$ petition will be filed in the first place and also presumes that petitioners with prior experience file the same types of cases as first-time petitioners. This may not be true. In particular, if experience lowers the cost of filing, it may lead to weaker cases being put forth by petitioners; in effect, a greater "working of the system." Thus, there may not only be a direct effect of prior

\footnotetext{
${ }^{1}$ Evidence for the discretion used by the USDOC in U.S. dumping margin calculations can be found in Boltuck and Litan (1991), Baldwin and Moore (1991), Lindsay (1999), Lindsay and Ikenson (2002), and Blonigen (2003).
} 
experience on $\mathrm{AD}$ outcomes, but a selection effect on filing costs from prior experience. To fix ideas, we begin by focusing on a firm competing against potentially multiple foreign import sources in one or more products. Given this, a firm will evaluate the following decision rule for each possible product and import source combination, $j \in J$, and file an AD petition for every combination that satisfies:

$$
\phi_{j}{ }^{A}\left(E, Z_{j}\right) \pi_{j}^{A}\left(D M\left(E, Z_{j}\right), Z_{j}\right)+\phi_{j}^{S}\left(E, X_{j}\right) \pi_{j}{ }^{S}\left(X_{j}\right)+\Psi\left(E, X_{j}, Z_{j}\right)>F C(E) .
$$

The lefthand side of equation (1) represents expected benefits from a case filing, where $\phi_{j}^{A}($.$) and \phi_{j}^{S}($.$) represent the probabilities of an affirmative or suspended decision, and$ $\pi_{j}^{A}($.$) and \pi_{j}^{S}($.$) represent the discounted non-zero profit from such outcomes, respectively.$ The probabilities of negative, affirmative and suspended outcomes sum to one and the profit gain from a negative outcome is assumed to be zero. These probabilities and discounted profit gains from affirmative and suspended outcomes depend on a set of other variables, including petitioner characteristics, macroeconomic conditions, industry/product features, and the nature of rivalry between the petitioner and its competitors, which are represented by $\mathrm{Z}_{\mathrm{j}}$ for affirmative decisions and $\mathrm{X}_{\mathrm{j}}$ for suspension agreements. ${ }^{2}$ The two sets of variables are potentially different because, for example, the variables in $\mathrm{X}_{\mathrm{j}}$ would include additional factors that would determine relative bargaining positions, which would affect the likelihood of the petitioner agreeing to a suspension agreement and the subsequent discounted profit gain it realizes from such an agreement. The discounted profit realized in the case of an affirmative outcome is affected by the size of the dumping margin, designated as DM. On the righthand side of the expression, FC designates filing costs and any other associated costs with being a petitioner in a U.S. AD case which we (1993), and Hansen and Prusa (1996, 1997) and Liebman (forthcoming). 
assume are identical across products. E represents the prior experience of a firm which will be the focus of our discussion below and is assumed to be firm-specific, not case-specific (hence no subscript j). Finally, $\Psi($.$) represents the expected discounted net benefit in future cases from$ filing this particular case and is assumed to be identical across the $\mathrm{j}$ products.

A number of possible scenarios can be represented with this framework and decision rule in equation (1), each with different implications for how previous experience translates into observed AD case outcomes. To explore this and narrow our focus, assume that the set of possible cases for a firm at a given point in time is a continuous set following a uniform distribution, $\Omega$, and that with no prior experience $(E=0)$, there is a subset of cases for which the expected benefits exceed the expected costs, $\Omega_{0}$. If $X_{j}$ and $Z_{j}$ are a composite index of factors for which both probabilities and discounted profits in the equation above, as well as the dumping margin, are increasing functions, then one can think of the set of cases in $\Omega_{0}$ as ones where the values of $X_{j}$ and $Z_{j}$ are sufficiently high. Initially, we will also assume that $A D$ duties placed in previous periods are not permanent. ${ }^{3}$ This condition implies that we have sampling with replacement from period to period, though below we will briefly discuss possible outcomes if we have sampling without replacement by firms in their AD filing behavior.

Given this set-up, we can now evaluate the possible effects of previous experience (E) on the decision to file an AD case and the average outcome of the case. First, suppose E only affects filing costs, not the probabilities of $\mathrm{AD}$ outcomes or the size of the dumping margin (partial derivatives of $\mathrm{DM}(),. \phi_{j}{ }^{A}($.$) and \phi_{j}{ }^{S}($.$) with respect to \mathrm{E}$ are zero). In this case, an increase in E only decreases filing costs, FC. The immediate result is a selection effect; a greater

\footnotetext{
${ }^{2}$ For simplicity, I assume that the same set of factors affect both the probability and the discounted profit in each of the two outcomes.

${ }^{3}$ This assumption is reasonably defensible. While there are examples of US AD duties that have been in place since the 1970s , the majority of orders from the 1970s and 80s have been revoked.
} 
number of cases will satisfy equation (1) and will mean increased filing by the firm. If prior experience does not affect AD outcomes, however, these newly selected cases will have lower probabilities of successful outcomes and lower dumping margins. Therefore, under this scenario we would expect the number of filings (or filing probabilities) to increase, while the average dumping margins and non-negative decision probabilities to decrease for petitioners with prior experience.

The opposite scenario would see the dumping margin and decision probabilities increasing in prior experience (E) with no effect of experience on filing costs. In this scenario, the dumping margin and probabilities of affirmative and suspended (or non-negative) decisions increase for all possible cases in the set, $\Omega$. Thus, the expected benefits of more cases exceed the filing cost threshold and we see filing activity increase. However, unlike in the previous scenario, we would see average dumping margins and non-negative decision probabilities increase, since the threshold benefit necessary to exceed costs remains the same. This assertion depends on the uniform distribution assumption on $\Omega$. If the mass of cases that switch from not being filed to being filed with an increase in experience is sufficiently large relative to the cases in $\Omega_{0}$ that would be filed regardless of experience, then it is possible that average dumping margins and non-negative decision probabilities do not increase or even decrease.

Perhaps the most-likely scenario is that greater prior experience increases dumping margins and non-negative decision probabilities while also reducing filing costs. Since both scenarios above led to increased filing, this scenario has the same prediction for filing activity. However, the effect on dumping margins and the non-negative decision probabilities is clearly ambiguous depending on the filing cost effect or the expected benefit effect from prior experience. If the filing cost effect dominates, we will see prior experience leading to lower 
average dumping margins and non-negative decision outcomes, whereas the opposite may occur if experience primarily affects the expected benefits side, not filing costs.

An alternative scenario that is not directly modeled by equation (1) is the possibility that firms are using AD filings to facilitate collusion or enforce tacit collusive arrangements. Such possibilities are raised in Prusa (1992) and in the discussion of "process filers" in Staiger and Wolak (1994). In such a scenario, the AD process may not play much, or any, role in expected benefits; such cases are unlikely to receive $\mathrm{AD}$ duties even if the investigation is completed and the $\mathrm{AD}$ authorities are not involved in negotiating a suspension agreement. Thus, prior experience can only affect the filing costs side. Thus, we should expect prior experience to have the same impact as the first scenario discussed above if $\mathrm{AD}$ filings are about facilitating or maintaining collusion - increased filings, but reduced dumping margins and non-negative decision probabilities if case investigations are actually completed. This scenario is perhaps the clearest case where prior experience allows firms to more effectively work the $\mathrm{AD}$ process to their advantage.

Finally, suppose that $\mathrm{AD}$ orders from previous cases are permanent - a condition sufficient for firms to sample cases to file without replacement. In this scenario, the firm would file a number of the strongest cases in the first period, allow learning effects to take place, and then file more (weaker) cases in the next period and so forth. If learning effects diminish with additional cases, this scenario without replacement would see filing activity ultimately decline. In other words, the effect of previous experience on filing activity will increase activity in periods immediately after the first period, but then we will see a slowing down as all the possible cases with net positive benefits get permanent $\mathrm{AD}$ duties. The dumping margins and nonnegative decision probabilities would again go down in this scenario just as the scenario with 
replacement, unless the learning effect is so strong that cases that were relatively weaker in the first period become stronger than the initial cases filed.

The rest of the paper will turn to the data to resolve these theoretical ambiguities over whether prior experience will increase or decrease dumping margins and non-negative decision probabilities, as well as how much such prior experience matters for AD filing activity. We begin with an initial look of descriptive statistics in the next section before turning to more formal statistical analysis.

\section{General Patterns of Repeat Petitioners in U.S. AD Cases}

In this section, I take a first look at general patterns of repeat petitioners in US AD cases. Before proceeding, it is important to note a data issue that affects the classification of repeat petitioners. In 1980, there were significant changes in US AD laws and the responsibility of calculating dumping margins was transferred from the U.S. Department of Treasury to the USDOC. After this point, more detailed public announcements of AD decisions also began to appear in the Federal Register notice on a consistent basis allowing for the development of detailed databases on US AD activity. In fact, US AD petitioners were not revealed publicly in the Federal Register prior to 1980 and therefore classification of repeat petitioners can only begin with a history truncated at $1980 .^{4}$ Thus, for the data analysis throughout the paper, I begin with a starting year of 1982 for the sample. Starting the sample at 1982 may not seem to allow enough history for these early years in the sample to yield a reasonable indication of whether the petitioner has prior experience. However, I note that the level of US AD activity prior to 1980 was substantially lower, suggesting that few firms were gaining experience during these years

\footnotetext{
${ }^{4}$ For a very small handful of cases, individual petitioners were not listed. Rather, a group association representing the manufacturers (and/or unions) was listed as the petitioner in the Federal Register notices.
} 
immediately prior to $1980 .{ }^{5}$ In addition, as I show below, $65 \%$ of the petitioners in 1982 cases already had prior experience in filing US AD petitions since 1980. Nevertheless, there are likely some firms in my sample that are classified as having no prior experience in US AD cases despite filing petitions prior to 1980 .

To begin, Table 1 lists all petitioners that filed at least eight additional US AD cases after their first filing (since 1980). ${ }^{6}$ I define a case as a filing against a particular product and country, following the USITC case numbering system. However, domestic petitioners often file simultaneously across multiple countries for the same product. ${ }^{7}$ Thus, the number of separate repeat incidences of filings by a firm (single or multiple petitions) is much lower than reported in Table 1.

The most striking pattern in Table 1 is that repeat petitioners in US AD cases are invariably steel firms. US Steel and Bethlehem Steel had 245 and 143 repeat cases, respectively, with the United Steel Workers of America labor union and National Steel next in line with approximately 100 repeat petitions each. An additional 31 steel firms were repeat filers in at least 8 cases during the sample period. These numbers compare to a total of 910 US AD cases filed from 1982 through 2000. Many of these cases were joint filings by various combinations of the steel firms and unions listed in a handful of large simultaneous filings across multiple steel products and countries. This includes a 34-case filing in 1982, a 23-case filing in 1985 and a 48case filing in 1992. Nevertheless, there were many other smaller filing incidences that occurred with repeat petitioners throughout the sample period. Repeat petitioner combinations in these

\footnotetext{
${ }^{5}$ Irwin (2004) provides an excellent analysis of US AD administration and activity prior to 1980 . Irwin has collected basic data on US AD cases and decisions prior to 1980, but not the petitioners involved in the case. ${ }^{6}$ A full listing of all petitioners in US AD cases from 1980 through 2001 can be accessed at the author's US AD page: http://darkwing.uoregon.edu/ bruceb/adpage.html.

${ }^{7}$ This is likely due to worries about trade diversion to another source that would mitigate the effects of protection for the domestic industry (see, e.g., Prusa, 1997). Also, Hansen and Prusa (1996) show that legal changes in the
} 
steel cases were not consistent throughout either. In the 1980s, US Steel and Bethlehem Steel were often filing together on flat-rolled steel products while other steel firms were filing cases together on such products as wire rope and wire rod. The large multiple filings in 1992 brought a group of 12 steel firms together as petitioners, headed by US Steel and Bethlehem Steel, while subsequent cases in the 1990s involved a much wider variety of petitioner combinations than in the 1980s. It also saw Nucor Corporation, and other minimills, become first-time and then repeat filers of US AD cases.

The second most active repeat filers after steel products are the producers of steel pipes and tubes. Cyclops Corporation is the most active repeat filers of this group with 40 filed cases, followed closely by a group of producers with 16 to 31 additional filings after their first petition. As with the steel cases, there are often simultaneous multiple filings across import sources in these cases, and petitions often saw a number of these firms listed as co-petitioners. Pipe and tube filings appear relatively frequently through out the sample and petitioner combinations are not constant.

After the steel and the steel pipes and tubes petitioners, the incidence of repeat filers falls off a significant amount. Torrington is the next highest with 14 cases, though these cases stem all from one filing incidence in 1990 after Torrington's first initial success with a filing in 1987. The next highest repeat petitioners are the Oil, Atomic and Chemical Workers labor union, with 14 repeat cases against imports of uranium, ferrosilicon, and silicomanganese, and DuPont with 11 repeat cases against a variety of chemical compounds. The other firms listed as repeat petitioners in other industries are primarily pipe fittings manufacturers that have filed a variety of cases over the sample.

middle of the 1980s allowing the USITC to examine the "cumulative" injury from all import sources named in the petition increased the incidence of multiple petitions. 
While there are many more incidences of repeat petitioners with less than eight repeat petitions in the sample in these "other" industries, it is clear that the majority of repeat petitions comes from the steel industry. Because of this, we will be careful to examine differences in results for steel versus non-steel cases in our analysis below.

Figure 1 provides another perspective on the data, presenting the proportion of cases each year from 1982 through 2000 that were by repeat petitioners. As mentioned above, by 1982 we already see a year in which the majority of petitions included at least one firm (or other organization) that had prior experience in filing a petition in the years since 1979. Over the entire sample, $54 \%$ of cases had at least one petitioner with previous experience in filing US AD cases. There are no obvious patterns that the incidence of filings by repeat petitioners increases over time and this is confirmed by not finding a statistically significant trend. One will note, however, that the three years with the highest total number of cases $(1982,1985$ and 1992) also have a greater than average proportion of repeat filers, and this is due to the large multiple country filings by the steel industry in these years.

One hypothesis is that petitioners with prior experience are savvier at timing their filings to correspond with macroeconomic conditions that make AD outcomes more favorable. Knetter and Prusa (2003) and Feinberg (2004) show that AD filings occur more often when a country's GDP growth and exchange rate are relatively weak. An implication is that periods with more filings would have a greater number of petitioners with prior experience, but there is no statistically significant correlation between number of cases in a year and the proportion of repeat filers. Likewise, there is no statistically significant correlation between the proportion of repeat filers and US real GDP growth or the exchange rate.

Before turning to statistical analysis of our hypotheses, Table 2 provides a simple comparison of means for US AD case outcomes related to our hypotheses. The first set of 
comparisons examines differences in $\mathrm{AD}$ dumping margins across cases with repeat petitioners and first-time petitioners. Dumping margins are approximately 11 percentage points lower (37.9\% versus $49.0 \%$ ) for cases with repeat petitioners involved versus ones with first-time petitioners. This relative comparison is fairly similar for both steel and non-steel cases.

This relationship is reversed in the next sets of comparisons examining the likelihood of achieving an affirmative decision or a suspension agreement, which is largely determined by the USITC injury determination. First, cases with repeat petitioners are more likely to receive an affirmative $\mathrm{AD}$ case decision (46.3\% versus $40.0 \%$ ). This result seems to be exclusively driven by non-steel products where repeat petitioners are $52.8 \%$ likely to achieve an affirmative outcome versus first-time petitioners who are only $40.2 \%$ likely to receive an affirmative decision. There is no such affirmative decision difference for steel cases, though very few steel cases are by first-time petitioners anyway. Suspension agreements tell a similar story with even larger differences in outcomes between repeat and first-time petitioners. Cases with repeat petitioners end in suspension agreements about $13 \%$ of the time, whereas cases with first-time petitioners see only $4.5 \%$ of cases lead to suspension agreements. This relative comparison is similar for steel and non-steel products though the general likelihood of suspension agreements for steel products is substantially higher than for non-steel products.

\section{Econometric Analysis of US AD Activity and Petitioner Experience}

We next turn to more formal statistical analysis of the effect of prior petitioner experience on US AD filings and outcomes. We begin with an estimation of the factors that explain $\mathrm{AD}$ filings across 4-digit Standard Industrial Classification (SIC) industries from 1982 through 1995, 
then turn to an examination of the size of dumping margins calculated by the USDOC in these cases from 1982 through 2000, and end with an estimation of the factors affecting the ultimate outcome of the case using data on decisions from 1982 through 1995. All three analyses begin in 1982 to allow for a reasonable measure of prior experience as discussed in the previous section. The ending dates of the sample depend on data availability for control regressors. ${ }^{8}$

\subsection{US AD Filing Activity}

A number of previous studies have examined determinants of US AD filing activity, including Feinberg (1987; 2004), Blonigen and Bown (2003), Knetter and Prusa (2003), and Blonigen and Park (2004). We examine the effect of prior experience on these filings while controlling for factors that previous studies find are important explanatory variables. Our dependent variable is a dummy variable indicating whether a 4-digit industry files an AD case in a given year. ${ }^{9}$ To examine the effect of prior experience we include a dummy variable indicating whether the industry has had prior AD cases filed since 1980. Given our analysis in section 3, we expect a positive coefficient. As represented in equation (1) as X and Z, we also include control factors that make non-negative decisions more likely and/or increase the profitability of a non-negative decision. Previous studies have found that three main factors affect filing behavior:

1) the "health" of the domestic industry, 2) the extent of import penetration in the industry, and 3) the size of the industry. The first two factors are indeed related to the economic factors that $\mathrm{AD}$ agencies examine in determining their decisions, while the latter factor is likely related to the

\footnotetext{
${ }^{8}$ The main limitation is the change in industry classification scheme from SIC to the North American Industry Classification System (NAICS) in the last half of the 1990s.

${ }^{9}$ One could also construct a variable that indicates the number of cases filed. However, given the level of disaggregation in these data, there are many observations with zeros. Thus, one obtains qualitatively identical results regardless of whether one uses the dummy variable approach for the dependent variable and estimates logit (as below in the text) or uses the number of cases and employs Poisson or negative binomial maximum likelihood techniques. Marginal effects of logit estimates are more readily understandable, so we choose the logit approach.
} 
industry's political influence. To proxy for the health of the industry we include real industry growth of the industry in our regressor matrix, expecting a negative coefficient. We also include import share for the industry, as well as the square of import share. Increased import share is expected to increase filings, though there may be a negative coefficient on the squared term to reflect less ability of the domestic industry to file as it becomes an ever smaller share of total US consumption. Following Knetter and Prusa (2003) we include an exchange rate index (foreign currency value of the US dollar) and expect filings to go up when the exchange rate increases (i.e, when foreign currencies depreciate relative to the dollar). ${ }^{10}$ We also include the number of employees in an industry as a size measure and expect a positive coefficient. Following previous literature, we lag these control variables one year as the $\mathrm{AD}$ agencies consider data previous to the case in making their decisions. ${ }^{11}$ We employ a random effects logit model to estimate via maximum likelihood techniques. Modeling industry random effects controls for any unobserved time-invariant industry characteristics that affect $\mathrm{AD}$ filing probabilities.

Table 3 provides random effects logit estimates of US AD filing activity across industries from 1982 through 1995. Column 1 provides estimates for the full sample, whereas column 2 drops the steel industry (SIC 3312) observations from the sample to gauge the sensitivity of the results to the inclusion of this industry that accounts for so much of the repeat petitioner activity. Both equations perform quite well, with all variables of correct sign and statistically significant and standard confidence levels. Import penetration share increases the likelihood of AD filings,

\footnotetext{
${ }^{10}$ Knetter and Prusa (2003) show that foreign currency depreciation has theoretically ambiguous effects on the likelihood of a successful AD outcome, as it make the injury decision more likely, but will reduce the expected dumping margin. However, their empirical analysis finds that the injury effect dominates.

${ }^{11}$ Data on AD cases by SIC code are available at http://darkwing.uoregon.edu/ bruceb/adpage.html. Prior experience by the industry in previous US AD cases was also tabulated from these data. Import penetration measures were constructed using trade data from the NBER Trade Database on trade flows by SIC from 1958-1994 developed by Robert Feenstra and domestic shipment data in the Manufacturing Industry Productivity Database developed by Eric Bartelsman, Randy Becker and Wayne Gray. Employee levels and real industry growth rates were also constructed from this latter database. The exchange rate term is a trade-weighted multilateral index of foreign currency price of the dollar taken from the Economic Report of the President.
} 
though at a decreasing rate as this share gets to higher levels. Higher employment levels also increase filing rates everything else equal, as does slower (or more negative) industry growth rates. Given how we define the exchange rate, the estimates suggest that foreign currency depreciation increases filing activity as well. The growth rate and exchange rate evidence is consistent with findings of Knetter and Prusa (2003) that uses country-level data versus the industry-level data employed in this analysis.

Prior filing experience has a statistically significant positive coefficient, confirming our hypothesis that such experience will increase filings. Calculating marginal effects from our coefficient estimates, we find that prior experience increases the likelihood of an AD petition by seven percentage points. This is quite large relative to a sample average of only a $2 \%$ probability of an AD filing for an industry in a given year. Thus, everything else equal, the filing probability for an average industry goes up from $2 \%$ to $9 \%$. These estimates clearly suggest that learning effects are substantial for US AD filing activity. Interestingly, the magnitude of this effect is virtually identical when we eliminate observations involving the steel industry which has been responsible for so many repeat petitions. As discussed in the theory section, if AD duties are relatively permanent, one would expect that greater previous experience could ultimately lead to lower filing probabilities as firms would deplete the inventory of cases for which filing brings expected net benefits. From this perspective it may be surprising that previous experience does not have a lower impact on filing probabilities for the steel industry as it has had a longer and more extensive history of filing AD cases than any other industry.

To further examine whether more extensive previous experience eventually reduces the previous experience effect on filing probabilities, we interacted the previous experience variable with a time trend, with the notion that previous experience in the latter half of the sample more likely represents a history of multiple instances of previous experience for the petitioners. This 
does uncover a diminishing previous experience effect on filing probabilities over time that is statistically significant and suggests that the effect is less than half in the latter years of the sample than the earliest years.

\subsection{US AD Dumping Margins}

We next turn to examination of prior petitioner experience on dumping margins calculated by the USDOC. The USDOC invariably finds positive dumping margins, so their decision is almost always affirmative and the real issue is the size of the dumping margin. Our focus in this section is whether prior experience affects the size of the dumping margin. To examine this we include a dummy variable that takes the value of " 1 " if any of the petitioners has been involved in a previous US AD petition and " 0 " otherwise. ${ }^{12}$ Our dependent variable is the dumping margin (in percentage) calculated by the USDOC for all cases from 1982 through 2000. These observations are firm-specific dumping margins as the USDOC calculates a unique dumping margin for each foreign firm that constitutes a significant portion of the investigated import volume. ${ }^{13}$ The sample contains over 1500 firm-specific observations with an average dumping margin of about $43.5 \% .{ }^{14}$ There is an average of 2.3 firm-specific dumping margins calculated for each $\mathrm{AD}$ case.

Calculations of dumping margins involve an examination of whether foreign firms' export price to the US is less than "fair" or "normal" value. Thus, the USDOC's dumping margin decision turns on firm-level data, not industry-level factors such as import penetration. We next discuss the practices and information used by the USDOC to calculate dumping margins

\footnotetext{
${ }^{12}$ An alternative variable that measures the percent of petitioners in the case that have prior experience yields qualitatively identical results.

${ }^{13}$ Smaller firms receive an "all other" dumping margin which is a trade-weighted average of the dumping margins calculated by the USDOC for the firms from the same country.
} 
and which suggest the factors that need to be included in our statistical analysis as control variables.

The first definition/proxy of fair value the USDOC turns to in their calculations of dumping margins is the price charged for the same product in the foreign firms' own home market. Oftentimes, this basic calculation has to be modified to account for circumstances surrounding the case and which are generally noted and documented by the USDOC in the Federal Register notices connected with the case. As has been shown by Baldwin and Moore (1991), Lindsay (1999), Lindsay and Ikenson (2002), and Blonigen (2003), these USDOC practices can have substantial effects on the size of the dumping margin and these announced modifications will serve as one set of explanatory variables in the statistical analysis. We describe these "special" USDOC practices next.

When the foreign firm does not sell the product to its own home market, the USDOC then may turn to data on exports to a third-country to calculate fair value. If these data are not available, then the USDOC turns to constructing a measure of fair value through a constructed cost methodology, whereby the USDOC estimates fair value as unit cost plus a profit margin. In the case of non-market economies, costs and prices are likely uninformative about true value of a product. In these cases the USDOC typically determines fair value by measuring the physical inputs necessary to build a product and then costing these components out using a comparable market economy (e.g., the USDOC may use price data from India to employ this methodology in cases involving China). There are also cases where the USDOC cannot obtain or verify information from the foreign firm that it needs to calculate fair value. In these cases, the USDOC turns to "facts available" which often involve information supplied by the petitioner. If

\footnotetext{
${ }^{14}$ Blonigen (2003) documents the rapid increase in US AD dumping margins from around $15 \%$ in the early 1980 s to over $60 \%$ by 2000 .
} 
the USDOC deems that the foreign firm is intentionally withholding information, the USDOC uses "adverse facts available", a punitive form of "facts available", which takes the highest dumping margin alleged in by the petitioners. Finally, in the case where the USDOC is using data on prices in the foreign firm's own market to calculate fair value, they will perform (when requested by the petitioners) a "cost of production test" whereby they examine whether some of the foreign prices are below unit cost. If so, they may disregard those below-cost prices, or all prices in some cases, in their calculation of fair value.

In summary, the following USDOC "special” practices may be used in dumping margin calculations and are announced publicly in Federal Register notices connected with the case: 1) third-country prices, 2) constructed cost, 3) non-market economy methodologies, 4) facts available, 5) adverse facts available, and 6) cost of production test. Dummy variables indicating the use of these practices (or not) form an important set of controls when investigating whether prior experience by the petitioner has an effect on the size of the dumping margin.

A final set of controls included in the analysis are country/region dummies and year dummies. The country/region dummies we use are for the major targets of US AD cases: 1) Canada, 2) Mexico, 3 ) Other Latin America, 4) Japan, 5) Korea, 6) Taiwan, 7) China, 8) Other Asia, 9) the European Union, and 10) the USSR/Russia (depending on year). Year dummies are important not only to control for macroeconomic factors that may affect dumping margin calculations, primarily exchange rate movements, but also legal changes to the US AD code, with the primary change occurring after 1995 due to the Uruguay Round. ${ }^{15}$ We also control for case-specific effects through a random-effects specification. Since cases are country-, productand time-specific, we are modeling any other unobserved effects across these dimensions that are not otherwise accounted for in our regressor set. 
Table 4 provides random effects estimates of US AD firm-specific dumping margins from 1982 through 2000. As with our AD filing estimates in Table 3, column 1 of Table 4 provides estimates for the full sample, whereas column 2 drops observations connected with cases involving the steel industry (SIC 3312). Overall performance of the regression models is decent with an $\mathrm{R}^{2}$ of 0.37 . The USDOC's use of "facts available" and "adverse facts available" has substantial impacts on the dumping margin. The use of "facts available" adds about 30 percentage points to the dumping margin, where as the use of "adverse fact available" adds about 64 percentage points - 71 percentage points when steel observations are eliminated. ${ }^{16}$ Other USDOC practices are not found to have statistically significant impacts on dumping margins. ${ }^{17}$ The coefficients on the country/region or year dummies are not shown for brevity, but both sets of dummy variables are jointly statistically significant.

Prior experience shows significantly negative impacts on the dumping margin for both the full sample and for a sample that excludes observations connected with steel cases. For the full sample, prior experience by at least one of the petitioners means a dumping margin that is 12.5 percentage points lower. This is substantial given an average dumping margin of $43.5 \%$. This evidence is consistent with a scenario where prior experience lowers filing costs for firms much more than it allows them to obtain higher dumping margins. Thus, there is primarily a selection effect that leads to many more relatively "weaker" cases being brought forward and lower average dumping margins for these repeat cases. When we eliminate observations with steel firms in column 2, the negative impact on dumping margins from prior experience is

\footnotetext{
${ }^{15}$ Further details on these legal changes can be found in Blonigen (2003).

${ }^{16}$ Since "adverse facts available" is a subset of "facts available", its impact on the dumping margin is calculated by adding the coefficients on both of these variables.

${ }^{17}$ Blonigen (2003) shows that USDOC practices besides "facts available" and "adverse facts available" are statistically important when one includes interactions of these terms with time trends. Employing similar interaction terms in this paper's specification confirms this, though it has almost no impact on our variable of interest - prior experience - so we present only these more basic regressions.
} 
somewhat lower in magnitude. This suggests that the selection effect of weaker cases is more pronounced for cases brought forward by the steel industry, the most active industry in bringing forward repeat cases.

A number of robustness checks were examined, none of which affected results. First, we used a variable that measured the percentage of petitioners on a case as our proxy for prior experience, rather than a dummy variable indicating only whether at least one petitioner had experience. This measure yielded a coefficient of -15.2 that was statistically significant, suggesting that if the case went from no petitioner having prior experience to all petitioners having prior experience, the dumping margin would be about 15 percentage points lower, everything else equal. An important alternative scenario that could explain the lower dumping margins is that cases with prior experience by petitioners are correlated with those where the foreign firms have prior experience as well. If the foreign firms can use their prior experience to greater advantage than the petitioning side, the net effect on the dumping margin would tend to be lower. To control for this potential hypothesis, we included a dummy variable for whether the foreign firm receiving the dumping margin had prior experience in our regression in column 1. The estimates show no evidence that foreign firm experience affects dumping margins with a coefficient of just over 1 and statistically insignificant, while the coefficient on prior experience by the petitioners is almost identical (-12.6) and remains statistically significant at the $99 \%$ confidence level. This provides further evidence for the hypothesis that weaker cases are being selected and petitioners' prior experience has relatively little impact on obtaining higher dumping margins.

\subsection{US AD Final Outcomes}


Our final analysis examines the potential effects of prior petitioner experience on final US AD outcomes. Since the USDOC invariably finds a positive dumping margin, leading to an affirmative decision on their part, whether an $\mathrm{AD}$ case ends in a final affirmative decision rests with the USITC's injury determination. The USITC rules affirmative about $50-60 \%$ of the time. Additionally, there are cases that are terminated due to suspension agreements between the US and foreign firms. Therefore, in this section we perform a statistical analysis of whether a case ends in one of three outcomes: 1) affirmative, 2) negative, or 3) a suspension agreement. ${ }^{18}$ As in the previous section, our focus variable is the prior experience of the petitioners and we proxy for this with a dummy variable that takes the value of " 1 " if any of the petitioners in the case has been involved in a previous US AD petition and " 0 " otherwise.

Since the final outcome relates directly to the expected benefits from filing, we use the same variables for control regressors as used in section 4.1 for the logit regressions explaining industry filing activity with one exception. The control regressors for section 4.1 analysis are at the 4-digit SIC level, whereas AD cases involve products that can comprise only a small part of any particular 4-digit SIC industry. It is difficult to get information for this product-level, except for the value of the products subject to the investigation. ${ }^{19}$ Thus, as an alternative for our import penetration measures, we use the data on the specific product's subject import value instead. This clearly is not an import penetration measure because it does not control for the size of the US domestic industry, but performs much better than the industry-level import measures in the regressions we present below. Importantly, results connected with our focus variable are not

\footnotetext{
${ }^{18}$ There are some cases which are terminated at the request of the petitioner without any indication of a suspension agreement. Some of these terminations are very early on before either agency has ruled and could just be due to poorly filed petitions. Others could be indications of tacit "suspension" agreements. For the results reported, here we record these cases as "negative" decisions. However, we report below changes to our results that occur when we alternatively classify these cases as "suspensions".

${ }^{19}$ Even these trade value figures are sometimes not publicly disclosed and have to be estimated from US trade data connected with the tariff-line codes which are always announced in the case. For more discussion, see Prusa (1997).
} 
affected by whichever measure we use. A final set of regressors is the same country/region dummies used in section 4.2 analysis. $^{20}$

We estimate the probability of the three possible AD case outcomes with a multinomial logit specification and present estimates in Table 5. For identification of the coefficients, we must normalize the effect of our regressors on a negative decision, so that estimates of coefficients for the affirmative and suspension outcomes should be interpreted as effects of the control variables on the dependent variable relative to a negative $\mathrm{AD}$ outcome. As with the previous sections, column (1) presents results for the full sample, whereas column (2) presents estimates from a sample that omits steel cases.

Overall, the fit of the specifications seem reasonable with chi-squared statistics easily rejecting the null hypothesis of jointly-zero coefficients and pseudo- $\mathrm{R}^{2}$ measures around 0.15 . The measures of import value of the investigated product have expected sign for both the affirmative and suspension coefficients, suggesting that greater import value raises the likelihood of these outcomes relative to a negative outcome, but at a decreasing rate. The exchange rate term is the expected sign in both, though only statistically significant in the suspension outcome set of coefficients. Once again, there are not any systemic differences between the coefficients from the full sample specification to those when steel industry cases are omitted.

Turning to our focus variable, we estimate a statistically significant positive coefficient for prior petitioner experience for both affirmative and suspension outcome probabilities relative to a negative outcome. The economic significance of this variable for these outcomes can be ascertained by comparing predicted probabilities of affirmative and suspension outcomes when the petitioners have prior experience versus when they do not have prior experience. Our estimates imply that the expected probability of an affirmative outcome is $54.4 \%$ for petitioners

\footnotetext{
${ }^{20}$ Inclusion of year dummies created statistical problems because some years saw no suspension agreements.
} 
with prior experience, everything else equal, versus $41.2 \%$ for petitioners with no prior experience. Likewise, prior experience increases the suspension outcome probability from $3.0 \%$ to $7.0 \%$. These learning effects on the non-negative decision probabilities contrast with the dumping margin results where previous experience led to lower dumping margins. The selection effect of weaker cases is clearly the same for the dumping margin and final outcomes, but these results suggest that learning allows firms to increase non-negative outcome probabilities enough to counterbalance the selection effect, whereas the opposite was true for the dumping margin calculation.

In the regressions described above, we classify a suspension outcome only when a public suspension arrangement was announced in the Federal Register notices connected with the case. This means that other cases that were terminated without a formal suspension agreement are classified as negative outcomes and ignores the possibility that these other terminated case may have led to private suspension agreements or facilitation of collusive behavior, which would be beneficial for a petitioning firm. Thus, as an alternative we examined a specification where we instead classified all terminated cases as "suspension" outcomes. With this classification of our dependent variable we estimate no statistically significant impact of prior experience on the suspension probability, though the effect on affirmative outcome probabilities continues to be statistically positive.

\section{Conclusion}

This paper has taken a first look at how previous experience by domestic firms with the US AD process (a proxy for learning) affects future $\mathrm{AD}$ filing probabilities and outcomes. The statistical analysis using data on US cases from 1980 through the 1990s suggests that while previous experience increases filing and affirmative outcomes, the size of the AD duties are 
significantly smaller for cases brought by experienced petitioners. The latter result is surprising, but may be explained by a selection effect - experience does not affect dumping margins as much as it lowers filing costs, leading to petitioning of weaker cases.

There is room in the future for a more sophisticated examination of learning in the $\mathrm{AD}$ process as there are a number of involved agents whose behavior over time may be affected by previous experience. This includes the foreign firms, the $\mathrm{AD}$ agencies making the $\mathrm{AD}$ determinations, and even the specialized legal teams that typically represent firms in these cases. ${ }^{21}$ This paper has developed a relatively informal model of AD filing decisions to motivate the empirical analysis, but clearly there is room for a more fully developed framework to understand the dynamic nature of the process that may yield important insights in the future as well. In addition, there may be heterogeneous groups of potential petitioners for which previous experience has differential effects. A related paper in this regard is that of Morck, Sepanski and Yeung (2001) that finds two types of political lobbyers in the steel industry for trade protection: occasional ones that only lobby under adverse market conditions and habitual lobbyers for which previous experience with the process is important. It would be interesting to examine the efficacy of such a framework for the filing and outcome behavior we find in AD activity.

\footnotetext{
${ }^{21}$ Examples of papers that examine various aspects of AD agency learning include Kohler and Moore (2001) and Bloingen (2003).
} 


\section{References}

Baldwin, Robert E. and Moore, Michael O. (1991) "Political Aspects of the Administration of the Trade Remedy Laws," in Richard Boltuck and Robert E. Litan (eds.), Down in the Dumps: Administration of the Unfair Trade Laws. Washington, DC: The Brookings Institution, 253-280.

Blonigen, Bruce A. (2003) "Evolving Discretionary Practices of US Antidumping Activity," NBER Working Paper No. 9625.

Blonigen, Bruce A. and Jee-Hyeong Park. (2004) "Dynamic Pricing in the Presence of Antidumping Policy: Theory and Evidence," American Economic Review, Vol. 94(1): 134-54.

Boltuck, Richard and Robert E. Litan (Eds.). (1991). Down in the Dumps: Administration of the Unfair Trade Laws. Washington, DC: The Brookings Institution.

DeVault, James M. (1993) "Economics and the International Trade Commission," Southern Economic Journal, Vol. 60(2):463-78.

Feinberg, Robert M. (2004) "U.S. Antidumping Enforcement and Macroeconomic Indicators: What Do Petitioners Expect, and Are They Correct?” American University Working Paper.

Hansen, Wendy L. and Thomas J. Prusa. (1996) "Cumulation and ITC Decision Making: The Sum of the Parts is Greater than the Whole," Economic Inquiry, Vol. 34(4): 746-69.

Hansen, Wendy L. and Thomas J. Prusa. (1997) "The Economics and Politics of Trade Policy: An Empirical Analysis of ITC Decision Making," Review of International Economics, Vol. 5(2): $230-45$.

Irwin, Douglas A. (2004) “Explaining the Rise of U.S. Antidumping Activity,” Mimeo.

Knetter, Michael M. and Thomas J. Prusa. (2003) "Macroeconomic Factors and Antidumping Filings: Evidence from Four Countries," Journal of International Economics, Vol. 61(1): 1-17.

Kohler, Phillippe, Michael O. Moore. (2001) "Injury-Base Protection with Auditing Under Imperfect Information," Southern Journal of Economics, Vol. 68(1): 42-59.

Liebman, Benjamin H. (forthcoming) "ITC Voting Behavior on Sunset Reviews, Weltwirtschaftliches Archiv.

Lindsay, Brink. (1999) The U.S. Antidumping Law: Rhetoric versus Reality. Washington, DC: Cato Institute.

Lindsay, Brink and Dan Ikenson. (2002) Antidumping 101: The Devilish Details of 'Unfair Trade' Law. Washington, DC: Cato Institute.

Moore, Michael O. (1992) "Rules or Politics? An Empirical Analysis of ITC Anti-dumping Decisions," Economic Inquiry, Vol. 30(3): 449-66. 
Morck, Randall, Jungsywan Sepanski, and Bernard Yeung. (2001) "Habitual and Occasional Lobbyers in the US Steel Industry: An EM Algorithm Pooling Approach," Economic Inquiry, Vol. 39(3): 365-78.

Prusa, Thomas J. (1992) "Why Are So Many Antidumping Petitions Withdrawn?" Journal of International Economics, Vol. 33(1-2): 1-20.

Prusa, Thomas J. (1997) "The Trade Effects of U.S. Antidumping Actions," in Robert C. Feenstra (editor), The Effects of U.S. Trade Protection and Promotion Policies. Chicago: University of Chicago Press (NBER).

Staiger, Robert W. and Frank A Wolak (1994) "Measuring Industry-Specific Protection: Antidumping in the United States," Brookings Papers on Economic Activity, Vol 0(Microeconomics): 51-103. 
Figure 1: Total U.S. Antidumping Cases and Proportion of Filings by Petitioners with Previous Filing Experience

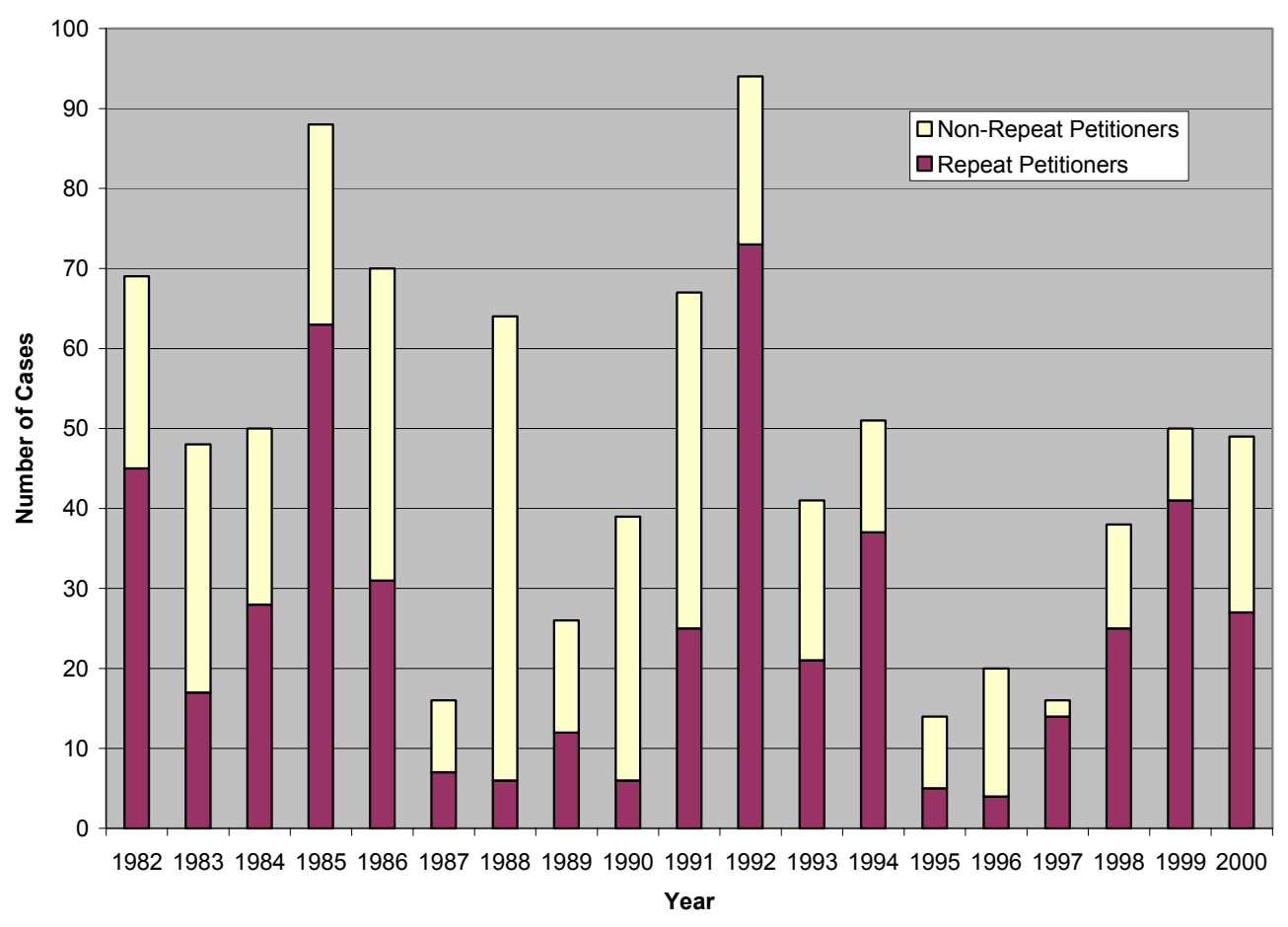


TABLE 1: Number of Filings by Petitioner After First U.S. AD Petition, 1982-2000: Most Frequent Repeat Petitioners.

\begin{tabular}{|llll|}
\hline Steel & & Steel Pipes and Tubes & \\
U.S. Steel Corp. & 245 cases & Cyclops Corp. & 40 cases \\
Bethlehem Steel Corp. & 143 & Sharon Tube Co. & 31 \\
United Steel Workers of America & 102 & Western Tube and Conduit Corp. & 28 \\
National Steel Corp. & 93 & Allied Tube and Conduit Corp. & 27 \\
Armco Inc. & 69 & Wheatland Tube Co. & 26 \\
LaClede Steel Co. & 69 & Bull Moose Tube Co. & 25 \\
LTV Steel Co. Inc. & 53 & Century Tube Corp. & 24 \\
Lukens Steel Co. & 49 & American Tube Co. & 22 \\
Inland Steel Industries Inc. & 48 & Southwestern Pipe Inc. & 21 \\
Sharon Steel Corp. & 48 & Maruichi American Corp. & 19 \\
Nucor Corp. & 47 & Maverick Tube Corp. & 16 \\
Steel Dynamics Inc. & 43 & Pittsburgh Tube Co. & 16 \\
Weirton Steel & 42 & & \\
North Star Steel & 36 & All Other Products & 14 cases \\
Carpenter Technology Corp. & 29 & Torrington Co. & 12 \\
Gulf States Steel Inc. & 27 & Oil, Chemical and Atomic Workers & 11 \\
Ipsco Steel Inc. & 22 & Du Pont & 10 \\
Altech Specialty Steel Corp. & 22 & Ladish Co. & 10 \\
Keystone Steel Inc. & 21 & Mill Iron Works & 10 \\
WCI Steel Inc. & 20 & Olin Corp. & 10 \\
Republic Steel Corp. & 18 & Steel Forgings Inc. & 9 \\
Georgetown Steel Corp. & 16 & American Brass & 8 \\
Co-Steel Raritan Inc. & 15 & Globe Metallurgical Inc. & 8 \\
Atlantic Steel Co. & 14 & Hackney Inc. & 8 \\
Northwestern Steel and Wire Corp. & 14 & Hercules Inc. & 8 \\
Raritan River Steel Corp. & 14 & Kaiser Cement & 8 \\
Continental Steel Corp. & 13 & Markovitz Enterprises (Flowline Div) & 8 \\
Talley Metals Technology Inc. & 12 & Silicon Metaltech Inc. \\
Allegheny Ludlum Corp. & 11 & Tube Forgings of America & 8 \\
Gallatin Steel Co. & 11 & & \\
GS Industries Inc. & 11 & & \\
Slater Steels Corp. & 10 & & \\
CF \& I Steel & 9 & & \\
TXI-Chaparral Steel Co. & 8 & & \\
Kaiser Steel Corp. & 8 & & \\
Nos: A rpeat ptition & & \\
\hline
\end{tabular}

Notes: A repeat petition is defined as any participation as a petitioner in a U.S. AD case after the firm (or organization) has had prior experience as a petitioner in any product since 1980. A unique case filing is defined by unique country-, product- and time-combination following the U.S. International Trade Commission's numbering system. Numbers in this table were tabulated from information provided in U.S. Federal Register notices accompanying these cases on petitioning firms and organizations. Data on petitioners by case can be accessed at http://darkwing.uoregon.edu/ bruceb/adpage.html. 
TABLE 2: U.S. Antidumping Outcome Comparisons Between Cases with Repeat Petitioners and Those Without Repeat Petitioners, 1982-2000.

\begin{tabular}{|ccc|}
\hline & $\begin{array}{c}\text { Cases with } \\
\text { Repeat } \\
\text { Petitioners }\end{array}$ & $\begin{array}{c}\text { Cases with } \\
\text { First-Time } \\
\text { Petitioners }\end{array}$ \\
\hline \hline Average Dumping Margin & & \\
\hline All Cases & & \\
Steel Cases Only & $\mathbf{3 7 . 9 \%}$ & $\mathbf{4 9 . 0 \%}$ \\
Non-Steel Cases Only & $38.3 \%$ & $41.6 \%$ \\
Affirmative Decisions & $37.6 \%$ & $49.6 \%$ \\
All Cases & & \\
Steel Cases Only & & \\
Non-Steel Cases Only & $\mathbf{4 6 . 3 \%}$ & $\mathbf{4 0 . 0 \%}$ \\
Suspension Agreements & $37.9 \%$ & $37.5 \%$ \\
All Cases & $52.8 \%$ & $40.2 \%$ \\
Steel Cases Only & & \\
Non-Steel Cases Only & $\mathbf{1 2 . 9 \%}$ & $\mathbf{4 . 5 \%}$ \\
& $19.0 \%$ & $12.5 \%$ \\
\hline
\end{tabular}

Notes: A repeat petition is defined as any participation as a petitioner in a U.S. AD case after the firm (or organization) has had prior experience as a petitioner in any product since 1980. A unique case filing is defined by unique country-, product- and time-combination following the U.S. International Trade Commission's numbering system. Numbers in this table were tabulated from information provided in U.S. Federal Register notices accompanying these cases. Most of these data can be accessed at http://darkwing.uoregon.edu/ bruceb/adpage.html and all data available upon request from the author. 
TABLE 3: Prior Experience and AD filings: Random Effects Logit Estimation of US AD Filing Probabilities Across 4-digit SIC Industries, 1982-1995.

\begin{tabular}{|c|c|c|}
\hline \multirow[b]{2}{*}{ Explanatory Variables } & \multicolumn{2}{|c|}{$\begin{array}{c}\text { Dependent Variable: " } 1 \text { " if petition; "0" } \\
\text { otherwise. }\end{array}$} \\
\hline & Full Sample & $\begin{array}{c}\text { Sample Without } \\
\text { Steel Industry (SIC } \\
3312)\end{array}$ \\
\hline Prior filing experience or not & $\begin{array}{l}1.464 * * * \\
(0.229)\end{array}$ & $\begin{array}{l}1.480^{* * *} \\
(0.225)\end{array}$ \\
\hline Control Variables: & & \\
\hline$\overline{\text { Import penetration share }}$ & $\begin{array}{l}0.082 * * * \\
(0.020)\end{array}$ & $\begin{array}{l}0.078 * * * \\
(0.019)\end{array}$ \\
\hline Import penetration share squared. & $\begin{array}{l}-0.001 * * * \\
(0.0004)\end{array}$ & $\begin{array}{l}-0.001 * * * \\
(0.0004)\end{array}$ \\
\hline Industry employment & $\begin{array}{l}0.004 * * * \\
(0.001)\end{array}$ & $\begin{array}{l}0.004 * * * \\
(0.001)\end{array}$ \\
\hline Real industry growth rate & $\begin{array}{l}-1.415^{*} \\
(0.725)\end{array}$ & $\begin{array}{l}-1.611^{* *} \\
(0.728)\end{array}$ \\
\hline Exchange rate index & $\begin{array}{l}0.022 * * * \\
(0.005)\end{array}$ & $\begin{array}{l}0.022 * * * \\
(0.005)\end{array}$ \\
\hline $\begin{array}{l}\text { Chi-squared statistic } \\
\text { Number of observations }\end{array}$ & $\begin{array}{l}117.35^{* * *} \\
5598\end{array}$ & $\begin{array}{l}225.48 * * * \\
5585\end{array}$ \\
\hline
\end{tabular}

NOTES: All variables are lagged one year with the exception of "Prior filing experience or not." Standard errors are in parentheses, with $* * *, * *$ and * denoting statistical significance (twotailed test) at the 1, 5 and 10 percent levels, respectively. 
TABLE 4: Prior Experience and AD Dumping Margins: Random-effects Estimation of US AD Dumping Margins, 1982-2000.

\begin{tabular}{|c|c|c|}
\hline \multirow[b]{2}{*}{ Explanatory Variables } & \multicolumn{2}{|c|}{ Dependent Variable: Dumping Margin } \\
\hline & Full Sample & $\begin{array}{l}\text { Sample Without Steel } \\
\text { Industry (SIC 3312) }\end{array}$ \\
\hline Prior filing experience or not & $\begin{array}{l}-12.45^{* * * *} \\
(4.04)\end{array}$ & $\begin{array}{l}-10.23^{* *} \\
(5.10)\end{array}$ \\
\hline Control Variables & & \\
\hline$\overline{\text { Facts available }}$ & $\begin{array}{l}30.03 * * * \\
(3.56)\end{array}$ & $\begin{array}{l}31.38 * * * \\
(4.01)\end{array}$ \\
\hline Adverse facts available & $\begin{array}{l}34.54 * * * \\
(4.06)\end{array}$ & $\begin{array}{l}40.17 * * * \\
(4.89)\end{array}$ \\
\hline Cost of production test & $\begin{array}{c}4.36 \\
(3.42)\end{array}$ & $\begin{array}{c}2.29 \\
(4.01)\end{array}$ \\
\hline Constructed value & $\begin{array}{c}0.69 \\
(3.27)\end{array}$ & $\begin{array}{l}-1.10 \\
(3.88)\end{array}$ \\
\hline Third country prices & $\begin{array}{l}-4.31 \\
(4.02)\end{array}$ & $\begin{array}{l}-3.14 \\
(4.32)\end{array}$ \\
\hline Non-market economy & $\begin{array}{c}4.40 \\
(8.95)\end{array}$ & $\begin{array}{l}-3.54 \\
(12.90)\end{array}$ \\
\hline Country/region dummies & YES & YES \\
\hline Year dummies & YES & YES \\
\hline R-squared & 0.37 & 0.37 \\
\hline Chi-squared Statistic & $726.53 * * *$ & $601.60 * * *$ \\
\hline Number of Observations & 1511 & 1090 \\
\hline
\end{tabular}


TABLE 5: Prior Experience and US AD Case Outcomes: Multinomial Logit Estimation of US AD Case Outcome Probabilities, 1982-1995.

\begin{tabular}{|c|c|c|}
\hline \multirow[b]{2}{*}{ Explanatory Variables } & \multicolumn{2}{|c|}{$\begin{array}{l}\text { Dependent Variable: " } 1 \text { " if affirmative; } \\
\text { "2" if negative; " } 3 \text { " if terminated/VER. }\end{array}$} \\
\hline & Full Sample & $\begin{array}{c}\text { Sample Without } \\
\text { Steel Industry (SIC } \\
\text { 3312) }\end{array}$ \\
\hline \multicolumn{3}{|l|}{ Determinants of Affirmative Outcomes } \\
\hline Prior filing experience or not & $\begin{array}{l}0.693 * * * \\
(0.190)\end{array}$ & $\begin{array}{l}0.720^{* * *} \\
(0.211)\end{array}$ \\
\hline Import value of investigated product & $\begin{array}{l}4.130 \\
(2.633)\end{array}$ & $\begin{array}{l}7.097 * * \\
(3.149)\end{array}$ \\
\hline Import value of investigated product squared & $\begin{array}{l}-4.78 \mathrm{e}-06 \\
(4.20 \mathrm{e}-06)\end{array}$ & $\begin{array}{c}-9.20 \mathrm{e}-06^{*} \\
(4.87 \mathrm{e}-06)\end{array}$ \\
\hline Industry employment & $\begin{array}{l}-0.002 * * \\
(0.001)\end{array}$ & $\begin{array}{r}-0.002 \\
(0.001)\end{array}$ \\
\hline Real industry growth rate & $\begin{array}{c}0.617 \\
(1.065)\end{array}$ & $\begin{array}{c}0.602 \\
(1.123)\end{array}$ \\
\hline Exchange rate index & $\begin{array}{c}0.008 \\
(0.006)\end{array}$ & $\begin{array}{c}0.010 \\
(0.007)\end{array}$ \\
\hline Determinants of Suspension Outcomes & & \\
\hline Prior filing experience or not & $\begin{array}{l}1.689^{* * *} \\
(0.465)\end{array}$ & $\begin{array}{l}1.376^{* * *} \\
(0.523)\end{array}$ \\
\hline Import value of investigated product & $\begin{array}{l}12.226^{* *} \\
(5.788)\end{array}$ & $\begin{array}{l}21.900 * * * \\
(6.451)\end{array}$ \\
\hline Import value of investigated product squared & $\begin{array}{c}-1.39 \mathrm{e}-05 \\
(9.40 \mathrm{e}-06)\end{array}$ & $\begin{array}{l}-2.83 \mathrm{e}-05 * * * \\
(1.05 \mathrm{e}-05)\end{array}$ \\
\hline Industry employment & $\begin{array}{c}0.002 \\
(0.002)\end{array}$ & $\begin{array}{l}-0.004 \\
(0.004)\end{array}$ \\
\hline Real industry growth rate & $\begin{array}{c}0.627 \\
(2.407)\end{array}$ & $\begin{array}{c}1.073 \\
(2.732)\end{array}$ \\
\hline Exchange rate index & $\begin{array}{l}0.072 * * * \\
(0.014)\end{array}$ & $\begin{array}{l}0.045^{* * *} \\
(0.016)\end{array}$ \\
\hline Country/region dummies & YES & YES \\
\hline Chi-squared statistic & $169.74 * * *$ & $101.66 * * *$ \\
\hline Pseudo $\mathrm{R}^{2}$ & 0.15 & 0.13 \\
\hline Number of observations & 607 & 476 \\
\hline
\end{tabular}

NOTES: All variables are lagged one year with the exception of "Prior filing experience or not" and country/region dummies. Standard errors are in parentheses, with ***,** and $*$ denoting statistical significance (two-tailed test) at the 1, 5 and 10 percent levels, respectively. 